\title{
赤外分光器の分解について
}

\author{
吉 原 邦 夫* \\ Resolution of Infrared Spectrometer
}

\section{Kunio YOSIHARA}

The resolution of infra-red spectrometer is discussed systematically on the basis of the papers of Strong, Walsh and others puplished recently.

First, it is proved for thermocouples and bolometers that the sensitivity-to-noise ratio is inversely proportional to the quare root of the sensitive area. Next, the Strong's formula for the amount of light which impinges on the detector through the exit slit is derived assuming that there are neither diffraction nor other factors which broaden the width of the spectral line. It the resolution of the spectrometer is kept constant, this amount of light $I$ can be written as

$$
\mathrm{I} \infty{ }_{\lambda}{ }^{2} \mathrm{~T} \mathrm{~T} \frac{\mathrm{A}}{\mathrm{f}} \frac{d \theta}{d \lambda} \delta \lambda^{2}
$$

where $\mathrm{J} \lambda$ is the spectral energy density at the entrance slit, $h$ the height of the slit, $\mathrm{T}$ the transmission factor of the spectrometer, A the area of the collimating merror, $f$ its focal length, $d \theta / \mathrm{d} \lambda$ the angular dispersion of the prism (or the grating) and $\delta \lambda$ the slit width measured in wave-len th scale.

Provided that the signal-to-noise ratio is constant, the minimum difference of wave-length $\delta \lambda$ which can be resolved is given by

$$
\left.\delta \lambda \infty^{\prime} f / \mathrm{KJ} \lambda h \mathrm{TA} \frac{d \theta}{d \lambda}\right)^{1 / 2}
$$

where $K$ is the sensitivity-to-noise ratio of the detector.

For thermocouple or bolometer sensitive area of which is necessarily limited and very small, this formula becomes

$$
\delta \lambda \propto(f / h \mathrm{~A})^{1 / 4}(\mathrm{~J} \lambda \mathrm{T} d \theta / d \lambda)^{-1 / 2}
$$

as was derived by Walsh.

Although the results obtained in this paper are not new, the proof of the theorem concerning the sensitivity-to-noise ratio of the detector, the derivation of the Strong's formula and some part of the following deduction are due to the author's own idea.

\section{1. 緒 言}

分光器の分解能は, 理論的に言えば Rayleigh の式で 与えられるわけであるが，実際には後にも述べるような 種々の制約があつて，てれより悪くなるのが通例であ る. 殊に赤外分光器においては, スペクトルのエネルギ 一の微弱なため, 又 detector の感度の悪いために更に 大きい制限が加わる。このような事実を考慮して，含迄 に多くの著者が分光器の分解に関する議論をしている.

ここではそれらの論交をもとにして，特に赤外分光器 を念頭に置いて分解能の問題を扱つて見よう.

2. Detector の面皘とその感度對雜音比

後に必要でああり, 邦交でこの問題を报つたものが無
いようなので，まずこれから考えるととにする（でてに ついては Jones がその有名な論文で抽象的に論じて, 感度対雑音比は detector の面積の平方根に逆比例する ことを指摘している，乙こでは，あつと具体的に例をあ げて検討して見よう。

第一に感度とは detector の受光面全体に単位エネル ギーが単位時間に大射する時に, detector の生ずる出力 電圧と定義する. とれは通常 volt/watt で表わす. 別に 受光面の単位面積に単位のパワーが大る時生ずる電圧と 定義することもあるが, 分光測光の場合には限られた光 束を detector に集中してその全面に当てるから始めの * 名古屋大学工学部応用物理学教室 
定義の方が妥当である. しかし今後の議論はこのような 場合にだけ成立するととに注意する必要がある。

次に雑音としては実際上の事を考えて, Johnson雑音, いわゆる熱雑音だけを採り上げると、これは detectorの 電気抵抗の平方根に比例する.

このような場合, detector $\mathrm{n}$ 倍に大きくしたとしよ う. (面積は $\mathrm{n}^{2}$ 倍) その大きくするやり方には色々な方沠 がありうる.

まず熱電対では，一つの熱電対をそのままn倍に抎大 した時を考える. 受光面と共に熱起電線の直径も $\mathbf{n}$ 倍之 なるが，長さはそのままに保つておく．すると受光面よ りの輻射損失, 線を伝わつて逃げる伝導損失は共に $\mathrm{n}^{2}$ 倍 となる. 従つて, 受光面全体に入る光量が同じならば. 温度上昇亡起電力は $1 / \mathrm{n}^{2}$ となる. しかしながら, 起電線 が太くなるための抵抗は前の $1 / n^{2}$ であり，熱雑音は $1 / n$ に減ずる. 結局感度対雑音比は $\left(1 / n^{2}\right) /(1 / n)=1 / n$ とな る. これは面積の平方根である. この場合熱起電線の長 さをn倍にしないのは，不自然のようであるが，輻射損 失と伝導損失が等しくなくてはならないという Johansen の条件から考えれば必らずしも不自然ではない.

次に熱電対の大いさを増すのに次のようなやり方もあ る. 即ち始めと同じ大きさの熱電対を縱横に $\mathrm{n}$ 行 $\mathrm{n}$ 列に 並へ，（Fig. 1）てれを全部直列につなぐ.

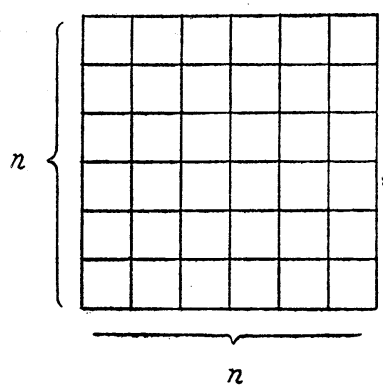

Fig. 1
この場合,一つの熱 電対にあたる光量は前 の $1 / \mathrm{n}^{2}$ となり, 起電力 についても同じである が，全部が直列になつ ているから，全起電力 は前の $\left(1 / \mathrm{n}^{*}\right) \times \mathrm{n}^{?}=1$ 倍で前と変らない。，そ のかわり，電気抵抗は $\mathrm{n}^{2}$ 倍, 従つて熱雑音は n 倍となり，感度刘雑音比は $1 / \mathrm{n}$ となる。

又との図で, 横の行は並列につなぎ，それらを縦に直 列につなぐと，温度上昇は $1 / \mathbf{n}^{2} て ゙ ，$ 起電力は直列にした あののみ加算されるから， $1 / n^{2} \times n=1 / n$ となるが，今度

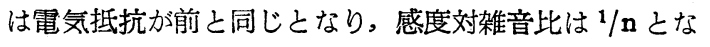
る.

同様に，熱電対を縱に一列に並べて何倍かし，直列に つないだ場合, 又横に一列に並べて並列につないだ場合 む, 感度対雑音比は面積の平方根に逆比例することは容 易に証明できる.

次にボロメーターの場合を考える.との場合ボロメ1
ターを流れる電流を I，抵抗を $\mathrm{R}$ ，その温度係数を $\alpha$ ， 光のあたつたための温度変化を $\Delta \mathrm{T}$ とすれば, 出力電圧 は $\frac{\mathrm{I}}{2} \mathrm{R} \Delta \mathrm{T}$ となる.Iはなるべく大きい方がよい が，余り大きくするとシュール熱のため破損するから適 当な值にきめておく．そこでボロメータ一の縦横をそれ ぞれ n 倍すると，これにかかる電压は $\mathrm{n}$ 倍してあよい. 何となれば，てのようにしてあボロメータ一の単位面積 あたり発生するジユール熱は前と同じで, 温度す同じと なり始めと同じ条件で働くからである，ての時は電流は 前の $\mathbf{n}$ 倍, 抵抗は同じである. しかし単位面積あたりの 光量が $1 / n^{2}$ となるから温度上昇は前の $1 / n^{2}$ である。乙れ より上の出力電压の式を用いると，その大いさは前の $\mathbf{n}$ $\times 1 \times\left(1 / n^{2}\right)=1 / n$ となる．抵抗は同じだから，熱雑音は 変らず, 感度対雑音比は $1 / \mathrm{n}$ となる。

次にボロメーターの巾は同じで，縦にだけ $\mathbf{n}$ 倍する. すると前と同じ理由で電圧は $\mathrm{n}$ 倍にでき, 抵抗が $\mathrm{n}$ 倍と なるから電流は変らない, 又面積が $\mathrm{n}$ 倍となるから, 光 量が同じならば温度上昇は $1 / n$ である。従つて上式から 出力電匠は $1 \times \mathrm{n} \times(1 / \mathrm{n})=1$ 倍となり，一方抵抗が $\mathrm{n}$ 倍 で, 雑音が $\sqrt{\mathrm{n}}$ 倍だから，感度対雑音比は $1 / \sqrt{\mathrm{n}}$ で面 積の平方根に逆比例する.

更にボロメーターの幅だけ $\mathrm{n}$ 倍にすると，電圧は前と 同じで電流は $\mathrm{n}$ 倍, 抵抗は $1 / \mathrm{n}$ となる.よつて出力電圧 は $\mathrm{n} \times(1 / \mathrm{n}) \times 1 / \mathrm{n}=1 / \mathrm{n}$ であるが，雑音が $1 / \sqrt{\mathrm{n}}$ とな るから求める比はやはり $1 / \sqrt{\mathrm{n}}$ である.

以上で Jones の結論が実際に成立するととが分つた。 但，上述の議論は若干の仮定を含んでいる．例えば熱電 対の場合はかなり無理な設計をしているし，ボロメータ 一の場合は輻射損失のみを考えて，伝導損失を無視して はる.しかし，てれらをよく検討して見ると気がつくこ とであるが，実際の場合は面積を增すと，上述の割合よ りもつと感度刘雑音比は悪くはなつても，よくはならな いであろう.

以前には熱電対をいくつか直列につないで見掛上感度 をよくした型のあのがしばしば使用されたが，現在のよ うに増巾法が発達して熱雑音が問題にされるようになる と, むしろエレメントは一つでも，その面積が小さい方 が却つて有利であることが結論される.

\section{Strong の式}

次に分光測光の場合，出射スリットを出て detector に入る光量を計算する．これには Strong の計算したよ く知られた式がある. それを以下導出する.

通常光源からの光は集光鏡 $M_{1}$ で入射スリット $S$ 上に 集められる. (Fig. 2) との時コリメーター鏡 $\mathrm{M}_{2}$ が定ま 
ればスリットとコリメーターとの距離は $\mathrm{M}_{2}$ の焦点距僬 fとなり，スリットよりコリメーターを見る立体角心は 定まる.すると集光鏡を最す有効に使用するには，それ がいを全部充すようにすべきであるから，その位置及び 大きさは図のようになる・しかも光源よりこの鏡を見る

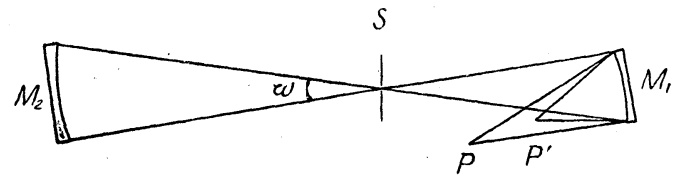

Fig. 2

角をできるだけ大きくしなくてはならないから，光線つ 邪魔をしない籁囲で傾きの角度が定まる. 鏡の焦点距離 はきまつているから光源の位置は自ら定まる.（図のP 点）乙れ以上光を集めることはできない. 集光鏡の焦点 距㒕を短かくすれば，光源の位置は例えば $\mathrm{P}^{\prime}$ に来て, より多くの光を集めることができるように見えるが，乙 のようにするとスリット上の光源の像が拡大され暗くな るから，簡単な計算より分るように利益は得られない. 結局コリメーターがきまれば，集光鏡はどのような焦点 距䗸のものを用いても同じことになる，のみならず収差 があると輝辰が減少するから，大気の吸収を考えなけれ ばむしろ或程度焦点距離の長いものの方がよい.

であるから以後スリット上には光源と同じ大いさの像 ができているあのとする.

入之 $\lambda+d \lambda$ の波長の間の連続光源よりの光の輝度を $\mathrm{J} \lambda$ $d \lambda$ 入射スリットの巾を $d$, 高さを $h$, コリメーターの 有効面積を $A$, その焦点距離を $f$ とする. するとコリメ 一ターに入る光量は $\omega$ が余り大きくないとして J $\lambda d \lambda h d$ $\frac{A}{f^{2}}$ である.乙の光は鏡で反射されたり，ブリズムを通 つたりする間に又ぞの面での反射によつて多少の損失を 受けるから，乙れを示す因子を $T$ として，出射スリット に向う時には $T J \lambda d \lambda h d \frac{\mathrm{A}}{f^{2}}$ となる.

出射スリットに大る光量を親するため，てれを含む スペクトルの像面上に入の增す方向にX座標をとる.

(Fig. 3)

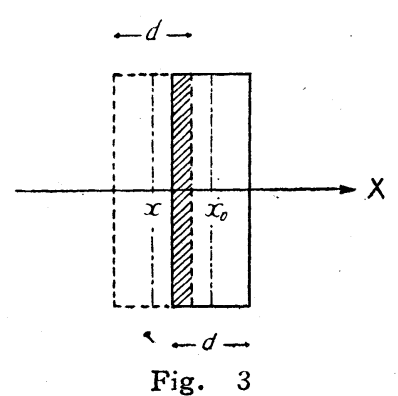

座標 $x$ と波長 $\lambda$ とは 一対一に対応する.今 簡単のため通常の Li一 ttrow 型分光器を考え るとコリメーター鏡と telescope mirror とは 同じものだからスペク トルは拡大縮小されな い. 従つて $x$ と $x+d x$
の間のスペクトル強度を $J_{x}$ とすれば

$$
\begin{gathered}
\text { Thd } \frac{A}{f^{2}} J_{\lambda} d \lambda_{\lambda}=J_{x} d x \\
\therefore J_{x}=T h d \frac{A}{f^{2}} J_{\lambda} \frac{d \lambda}{d x}
\end{gathered}
$$

Fig.3で実線つ矩形を出射スリット，点線の矩形を或 波長の入射スリットの像とする・但し回折等の無い理想 的な場合を考えるものとする. 出射スリットの中心位置 の座標を $x_{0}$ ， 入射スリット像の中心を $x$ とする. 乙れ らはスリットの無限に狭い場合の夫々の位置に相当し, $x_{0}$ は分光器の波長目盛に印された波長に相当する.

光源が連続であるから，点線で表わしたような入射ス リットの像が相重なつて並んでいるわけである. それ故 出射スリットより出てゆく光量は, 入射スリットの像之 出射スリットとが重なる部分 (図の刹楾つ部分) の光量 を種々の $x$ (即ち種々の波長)について加え合せれば得ら れる・とれをI とすれば

$$
I=2 \operatorname{Th} d \frac{A}{f^{2}} \int_{x_{0}-a}^{x_{0}} \pi \lambda \frac{d \lambda}{d x}\left\{d-\left(x_{0}-x\right)\right\} \frac{1}{d} d x
$$

ここで, 通常そうであるように，出射スリットの币は 大射スリットの巾に等しいとしてある. 2 という因子は $x$ が $x_{0}$ を過ぎると対称的に減じてゆくから, 積分範囲 を半分にしたかわりに二倍したことを示す. $J \lambda$ と $\frac{d \lambda}{d x}$ はこの㹂囲で-定と仮定すると

$$
\begin{aligned}
I= & 2 \operatorname{Th} d-\frac{A}{f^{2}} J_{\lambda} \frac{d \lambda}{d x}\left[d x+\frac{1}{2}\left(x_{0}-x\right)^{2}\right]_{x_{0}-d}^{x_{0}} \\
& =T h d 2 \frac{A}{f^{2}} J_{\lambda} \frac{d \lambda}{d x}
\end{aligned}
$$

プリズム，又は回折格子の角分散を $\frac{d \theta}{d \lambda}$ とすれば， $d x=f d \theta$ より

$$
I=T h d^{2} J_{\lambda} \frac{A}{f^{3}} \frac{\frac{1}{d \theta}}{d \lambda}
$$

これを Strong の式と言い，准々引用されるものであ る.とれで見ると，Iは $f$ の三乗に逆比例し，角分散に 逆比例するのであるが，実際には分解と関聯して考えね ばならないのでやや異つた式となる. 即ち焦点距離を長 くすればスぺクトルの像がひろがるからスリット币を增 して前と同じ条件になるし，又分散 $d \theta / d \lambda$ 戟せばスリ ツト巾を増しても分解は変らない. それ故分解一定とい う条件では

$$
d=\text { const. } f \frac{d \theta}{d \lambda}
$$

となる.との const. は分光器の性質によらないが, ス リットの波長巾 $\delta$ 凤 に比例するから，結局 


$$
d \propto f \frac{d \theta}{d \lambda} \delta \lambda
$$

とおいてよい. 乙れを(2)式代入して

$$
\left.I \propto J \lambda h T \frac{A}{f} \frac{d \theta}{d \lambda} \delta\right)^{2}
$$

この式を見ても分るように，I を增すために $f$ を短か くした時はこれに反比例して有利となるが，角分散の方 は乙れが大きい程有利となる.実際, 現在は detectorの 感度の向上と, 増巾法の進歩とのためにプリズム分光器 でも簡単な気体ならば微細構造も測定できるようになつ たが，昔は回折格子のような分散の大きいものを使用せ ねばならなかつた。

(3)式は detector が光電管などのような受光面が相当 にひろく, 光の当て方が c itical でないむのについては そのまま成立つが, 熱電対やボロメーターのように狭い 受光面（1 mm²はそれ以下）に正確に光を集中しない と出力の激减するすのについては異なる考えが必要であ る.

この場合光を集中させるつに通常楕円面鏡を用いるが・ まず簡単のため球面鏡を用いたとし，鏡から detectorま での距離は鏡から出射スリットまでの距離に比してずつ と小さいとする．乙の条件は像を相当縮少するのである から大抵の場合成立つと考えてよい。そしてての縮少率 は像のぼけない程度で可能な限度まで持つて行つてある あのとする. 今コリメーター鏡の $f$ を $1 / \mathrm{n}$ 亿減ずると出 射スリットより出る光束の角度は $\mathrm{n}$ 倍にひろがる.これ を全部集めようとすれば前の $\mathrm{n}$ 倍の直径の鏡を用いねば ならないが，たら゙そうした鏡を用いると収美のため像が ぼけて光を有効に受光面に集中できなくなる・てれを避 けるためには鏡の焦点距離も $\mathrm{n}$ 倍にし，スリットの像, 従つて detector 屯鏡から $\mathrm{n}$ 倍の距離にずらせばよい. この時は detector から鏡を見る角度は前と同じになる から収美は前の場合と同程度になり明瞭な像を生ずるの で光を全部有効に受光面に集中できる.しかしながらこ のようにすると像の大きさは前の $\mathrm{n}$ 倍(面積は $\mathrm{n}^{2}$ 倍)とな る・但，分解を前と同じにするためにスリット巾は $1 / n$ としてよいから，生じた像の面積は結局前の $\mathbf{n}$ 倍となり detector むとれに応じて大きいものを用いなくてはなら ない．前節に述べたところにより，この場合detectorの 感度刘雑音比は. $1 / \sqrt{\mathrm{n}}$ となるので（3）によつて detector に入る光は $\mathrm{n}$ 倍であ $\mathrm{S} / \mathrm{N}$ は $\mathrm{n} / \sqrt{\mathrm{n}}=\sqrt{\mathrm{n}}$ 倍に しかならない. A，hについても同様で

$$
S / N \propto J \lambda T\left(\frac{h A}{f}\right)^{1 / 2} \frac{d \theta}{d \lambda} \sigma \lambda^{2}
$$

が成立つととになる。
棈円面鏡の場合は事情が複雑上なるが，光束の角が $\mathrm{n}$ 倍になつた時, 鏡の位置とスリット（鏡より遠いううの焦 点）の位置とを固定し，鏡に近い方の焦点を鏡より $\mathbf{n}$ 倍 の位置にずらすように別の鏡を用いれば，上述と似たよ うな考察が或程度通用する. 従つて(4)はやはり近似と して成立つと思われる。

更に以上においては，光束のひろがつた時像のぼける のを構わずたぐ大きな鏡を用いるよりあ，像を（従つて detector あ) 大きくしてあぼけを除いた方が有利である と仮定した. 奏際にこの何れがよいかは疑問のあるとと ろで, 正しい判定には複雑な計算が必要である.ととに 交流增巾の場合 detectorを大きくしたため時定数が長く なる恐れがある時はなおさらである・こてでは，ぼけを 除いた場合の方が取扱いが簡単であるからてれを採用し たのであつて, 従つて(4)式の $1 / 2$ という指数は一つの 目安にすぎない.ただ，䓡電対やボロメーターの場合は (3)式で与えられるよりも，fを小さく(叉は A, hを 大きく）することにより得られる堵果は相当に少いとと は確かである。

(detector の大きさによる時定数の変化は熱電対の場 合は熱の伝導損失のため複雑であるが，ボロメーターの 場合は伝導損失は通常小さいと考えられるので比較的簡 単である. 即ちその厚さは同じで面積をn倍にすれば， 熱容量すn倍になるけれどあ，輻射損失す $\mathrm{n}$ 倍になるか ら時定数は変らない. 但し厚さを同じままにして面積を n 倍にするとボロメーターか破損しやすくなる場合は, 厚さむ同時に增さなくてはならないので事情が異なつて 来る)

Walsh ${ }^{(4)}$ は次節に述へるように分解の見地からやや異 なる考察をした。

\section{4. 分 解}

detector の感度対雑音比をK亡すれば，I なる強さの 光が入射した時のその信号対雑音比 S/N は IK である. (3)よりこの場合は

$$
\left.S / N=\text { const } \cdot K J \lambda_{\lambda}^{\prime \prime h} T \frac{A}{f} \frac{d \theta}{d \lambda} \delta\right\rangle .2
$$

䒠際の測定にあたつては，乙の $\mathrm{S} / \mathrm{N}$ が相当大きくな ければスペクトルの満足な記録はできない。そそこで $/ N$ を一定に保つた時どの程度までの波長差を分解できるか 考えて見る.今，回折現象等を無視すれば，出射スリッ ト面上の入射スリット像は単色光に対しては Fig.3のよ うに正しく短形となるから，プリズムと鏡を回転してス ペクトルを移動させた時出射スリットより出る光の強さ は Fig.4(a) のように三角形状に変化する.との三角形 


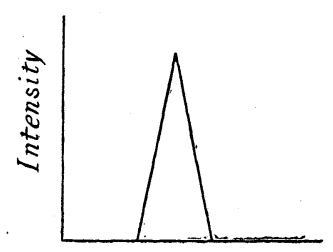

(a)

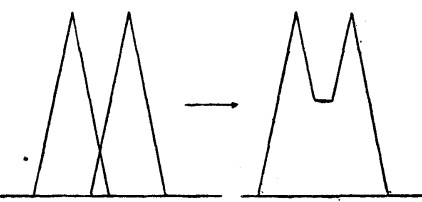

(b)

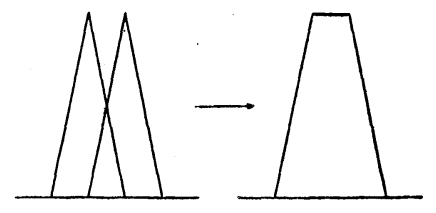

(c)
の底辺の長さは $2 d$ である.二つのスペ クトル線が接近して 存在する時，その中 心間の距㒕が $\mathrm{d}$ 以上 ならば (b)図のよう に合成したものの強 度は中央が凹むから 区別できるが，d に 等しくなると (c) 図 のように梯形となり 一本の線と区別でき ない. dより小さい 場合はなおさらであ る.

それ故分解可能の 極限は，距㒕 $\mathrm{d}$ まで であると考えられる

Fig. 4

が，これはちようど スリットの巾にあたる，スリット币が波長巾 $\delta$ 亿相当

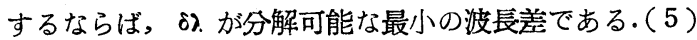
式の $\delta \lambda$ はこの意味であるから $S / N=$ 一定の条件では o) $\propto\left(f / K J_{\lambda} h T A \frac{d \theta}{d \lambda}\right)^{1 / 2}$

この式についても前と同じように，光電管などにはそ のまま適用できるが，熱殗対などの場合は

$$
K \propto(f / h A)^{1 / 2}
$$

であるととが推論されるから結局

$$
\delta \lambda . \infty(f / h A)^{1 / 4}\left(J_{\lambda} T \frac{d \theta}{d \lambda}\right)^{1 / 2}
$$

となる.この式によれば,コリメーターの焦点距離を短 かくして光を強く集め性能を高めようとすることは. 分 解の点よりすれば殆んど無意味に近いことが分る，例え ぱ分解を 2 倍にしようとすれば，焦点距離を1/16 にしな くてはならない，乙のような分光器を設計しようとする 人は居ないであろう．実際に研究室に用いられている分 光器を見ても， $f$ は Perkin Elmer の $27 \mathrm{~cm}$ より Leitz などの $81 \mathrm{~cm}$ のものまで色々あるが，外の条件が同じな らば，o，の比は約 $1-3$ 倍にしか過ぎない。のみならず 分光器が大きければ $A Ｉ$ あ従つて大きくなるから事実 上の性能は殆んど変らないであろう。

又、コリメータ一鏡の直径を大きくしたり，スリット の長さを增したりする試ろみについてむ同じであつて， 要するにそうした簡単なととで分解を増そうとするのは 殆んど無䭾だというととになる。
分 光 研 究 第 5 巻・第 2 号 (1957)

して見ると分解を良くするには，（1）detector の性 能を向上させて,その固有の感度対雑音比を大きくする. (2)強力な光源を用いる. (3) 分散 $d \theta / d \lambda$ を大きくす る.の外は無い。（1）については，現在特に熱起電力の 大きい物質や特に抵抗の温度係数が大きくて雑音の少い 物質の得られる見迈が少い限り飛躍的な性能向上は望め ないが，乙れに向つて努力が続けられているてとは事実 である. dctector の形状を小さくすることは，直接感度 対雑音比を大きくする点です，熱容量が小さくなり従つ て時定数が短かくなる結果交流增巾の場合は事実上感度 がよくなるという点です考慮に值するが，技術的な困難 は別にしても，出射スリットよりの光束を有効に集中で きる非球面鏡が簡単にできなければやはりその効果は少 (2.

(2)については Strong 等が特に意を用いたあので， V形のタングステン・リボンや安定なカーボンアーク等 に関する論交 $^{(8)(y)}$ があるが，これらは確かにグローバー に比して強力ではあつても，萺置が大脚りになるため十 分害用的とはいわれないようである.しかしとの方向の 研究は大切である.

(3)は Walsh が着目した点であつて，苓の結果は彼 の double pass ${ }^{(4)}$ 又は multiple pass の分光器とな つて現われた.

この方法によれば分散を比較的容易に数倍にすること ができ, 実際に発表されたスペクトルの記録すその性能 を証明している.(邦交では例えば工藤・宮崎の論交) こ の場合注意すべきとと，第一に（6 式より明らかなよ うに $\mathrm{S} / \mathrm{N}$ 一定の条件では $\delta \lambda$. は分散の平方根に逆比例 するから，分散が $\mathrm{n}$ 倍になつてあ分解は $\sqrt{\mathbf{n}}$ 倍にしか ならないということである。発表されたデータあ略々て れを裏書きしている．第二に光を何度すプリズムを通す ようにすると，鏡面及びプリズム面での反射損失，プリ ズム及び大気の吸収による損失が次第に顕著になり（6) 式のTが小さくなるので分散の増加による利登が或程度 減殺される. 第三に何度む光を往復させると光束がコリ 一ターに対して次第に軸外れの度が増し収差が著しくな り，とれを避けようとすると光束を断続するのか非常に 团難となる・第四に multiple pass ではスリットの像の 曲りが甚しくなるので，光をうまく断続するに入射スリ ツトの方を直線状にし，出射スリットの方を曲げなくて はならない. すると出射スリットよりの光を detector の上に集めにくくなる.

このような種々の理由により現在までには quadruple passまでのものしか作られていないようである・(市販で 
は double pass まで) これより分解を上げるには回折 格子, 特にエンエレットの方が得策なのであろう.

\section{5. 回折等を考虑した場合の分解}

前節の議論は回折はなく光学系の完全な理想的な場合 であつた。これらの存在する実際の場合については，現 にあげた交献に論じられているが，結果が一般に複雑な ので Brodersenによる簡略な形を引用するととにす る. それによると分光器のスリット巾を無限に小さくし た時にも次のような原因で出射スリットを出る光は無限 小の波長巾とならない.

(1)回折 (2)スリツトの曲りの不一致 (3)収差 (4)光学面の理想的でないとと（5)プリズム材質の不 均一, 又は回折格子の ruling の不完全 (6)光学系の 調整の不完全（7)スペクトルの自然巾・

この有限な币のスペクトルの形をガウスの正規曲線で 表わせると仮定すれば，その半值巾は以上の原因化よる 巾の和として書くことができる．とれを $d_{0}$ とする・本 節では便宜上波長のかわりにその逆数の波数をとり，

Fig.3 のX座標に入でなくvを対応させる. そして $d_{0}$ も波数の目盛で測るとする。そてでスリット巾の有限な とき実際の幾何学的なスリット巾(今迄のd) を波数で 測つて $d_{g}$ とすれば，出射スリットを出る光は，通常 Fig. 4 (a) のような三角形に近いと考えてよいが，ただ その半値巾が $\boldsymbol{d}_{\mathrm{g}}$ でなく, 次の式できまる有効巾 $\mathrm{d}_{\mathrm{eff}}$ $\left(\mathrm{cm}^{-1}\right)$ を持つようになる.

$$
\mathrm{d}_{\mathrm{eff}}{ }^{2}=d^{2}+d^{2} g
$$

却ち，等価的には出射スリットを出る光は実際のスリ ツト巾 $d_{g}$ より大きく $d_{\text {eff }}$ にひろがると考えてよい. deff が $d_{g}$ により変る有様は Fig. 5 に示してある. $d_{g}$ が $d_{0}$ より大きい 時は $\mathrm{d}_{\text {eff }} d_{g}$ で あつて前節の議論 はそのまま成立つ. $d_{g}$ が $d_{0}$ 亿等しい か，小さい所では $\mathrm{d}_{\text {eff }}$ は $d_{g}$ に殆ん どよらない.とれ は $d_{0}$ よりスリッ トを狭くしても信 号が弱くなり，

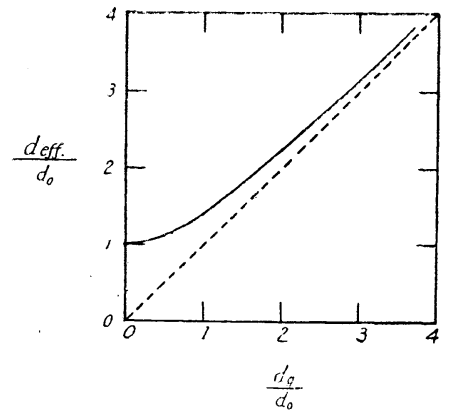

Fig. 5
$S / N$ が悪くなるだけで分解は増さないととを意味する。 これを改善するには $d_{0}$ 自身を小さくする外はない， $d_{0}$ は上述のように色々の原因によるから簡単に数式化でき ないであろうが，少くとも分解をよくすれば小さくなる ことは確かである.とのようにして前節の終の結論はや はり殆んど変更されない. 即ち, まず detector の性能 を向上させることと，光源を強力にするととによつて $\boldsymbol{d}_{\boldsymbol{g}}$ が $\boldsymbol{d}_{0}$ に等しいかそれ以下になつても $\mathrm{S} / \mathrm{N}$ が十分 な大きさにたるようにし，同時に分散をよくすることで $d_{0}$ を小さくする以外に分解を增す手段は存在しない.

6. 結 び

以上 Strong の式をもとにして分光器の分解を取扱つ た. 最後の結論は分り切つたてとでしかないが，途中の 式によつて分光器のどういう因子が分解にどのような影 響を及ぼすかを知ることは大切である。

なお，上に導いた式はすべて新しいものではないが， 第一節の感度対雑音比に関する定理の証明, Strong の 式の導き方，及び Walsh の式の導き方の一部は著者の 考えによるあのであることをお断りしておく.

又，Golay による multi-slit の方法は分解を改善す るというより明るくすることが主眼と考えられるのでて こでは触れなかつた：

\section{文献}

(1) J. Strong: Phys. Rєv. 37, 1661 (1931)

(2) J. Strong: J.Opt.Src. Am. 39, 320 (1949)

(3) G. W. King and A. G. Emslie: J.Opt.Soc. Am. 41, 1 (1951)

(4) A. Walsh: J.Opt.Soc.Am. 42, 96 (1952)

(5) S. Brodersen : J.Opt.Soc.Am. 43, 877 (1953)

(6) S. Brodersen: J.Opt.Soc.Am. 44, 22(1954)

(7) R. C. Jones: J.Opt.Soc.Am. 39, 327 (1949)

(8) J. H. Taylor, C. S. Rupert and J. Stro g : J. Opt.Soc.Am. 41, 626 (1951)

(9) C. S. Rupert: J.Opt.Soc.Am, 42, 684 (1952)

(10) N. S. Ham, A. Walsh and J. B. Willis : $J$. Opt. Soc.Am. 42, 496 (1952)

(11) A. Walsh and J. B. Willis : J.Opt.Soc.Am. 43, 989 (1953)

(12) 工藤・宮崎：伈用物理 24，461（1955） 